\title{
Accounting \& Finance, a close relationship
}

\author{
Fernanda Finotti Cordeiro ${ }^{1}$ \\ (D) https://orcid.org/0000-0002-5801-5278 \\ Email: fernandafinotti.cordeiro@ufjf.edu.br \\ ${ }^{1}$ Universidade Federal de Juiz de Fora, Faculdade de Economia, Programa de Pós-Graduação em Economia, Juiz de Fora, MG, Brazil
}

Correspondence address:

Fernanda Finotti Cordeiro

Universidade Federal de Juiz de Fora, Faculdade de Economia, Programa de Pós-Graduação em Economia

Campus Universitário - CEP 36036-330

Martelos - Juiz de Fora - MG - Brasil

I have the habit of saying that accounting is the grandmother of finance and, as such, should be respected and understood by all who venture to test and reinvent financial theories. For this edition, I was given the task of writing an editorial that seeks to highlight the umbilical relationship between accounting and finance, a topic within the "Financial market and companies/stakeholders integration" research line of this Journal, which I have the privilege of coediting. As a researcher currently working in economics, I have given myself the poetic freedom of also relating that area of study to accounting and finance.

\section{THE GRANDMOTHER}

To begin the endeavor, I will borrow the knowledge passed on to me by my PhD mentor in financial theory, Professor Rubens Famá. In order to represent the influence of accounting on finance, the professor highlighted, in his classes, the thoughts of Benedetto Cotrugli and Luca Pacioli. Benedetto Cotrugli (Kotruljevic in Slavic) was the first author in accounting to establish the "doubleentry" method. His work (Della mercature e del mercante perffeto) was written in 1458, listing some general rules for accounting for commercial operations, albeit in an incomplete way. The incompleteness and delay in publishing the work left Cotrugli behind Luca Pacioli, an author who subsequently wrote about the same topic and who has gained prominence in the history of accounting. Luca Bartolomeo de Pacioli was an Italian monk and mathematician. In 1494 in Venice, he published his work Summa de arithmetica, geometria proportioni et propornalità, a collection of knowledge on arithmetic, geometry, proportion, and proportionality, with a chapter dedicated to accounting - Particulario de computies et scripturis - with its description of the famous double-entry (or Venetian) method. To this day, the method enables the three main financial decisions of a country and a business to be viewed quickly and in full: that of investment, that of financing the investment, and that of distributing the earnings derived from the first two decisions.

Until the first half of the $20^{\text {th }}$ century, the study of finance was a hazy area focused on describing institutional, accounting, and legal problems. The mathematical models applied were restricted to calculating the value of money in time and of the present value of companies. In large part, accounting and finance were twin fields, especially considering the American school of accounting, which was geared more toward practical rather than theoretical aspects of the area. According to Iudícibus (1997), around 1920 , large corporations were already emerging in the United States of America; the country faced significant development of the real economy and the capital market, which required heavy investment in research in the accounting area. It is no coincidence that the American Institute of Certified Public Accountants (AICPA) is a pioneering accounting research body in the world. The American school, unlike the Italian one, was concerned with the user of accounting information. In Brazil, there 
was an influence of both the Italian and the American school. The former was taught at the Álvares Penteado School of Commerce, created in 1902 and a pioneer in the teaching of accounting, hosting important names in accounting research, such as Francisco D'Auria, Frederico Herrmann Júnior, and Coriolano Martins. The latter influenced the formation of Brazilian corporate law (Law n. 6,404 of 1976).

\section{THE MOTHER}

With the introduction of the double-entry accounting method, there was a necessary systematization of studies in economics, beginning with the accounts of nations, or national accounts (production, income, employment, etc.). According to Hallak (2014), various authors contributed to the building of national statistics based on double entry, among whom William Petty stands out, with his essay Political arithmetical (1690), which sought to carry out the first estimations of national wealth in England (investment decision), along with François Quesnay, with his work Tableau économique (1758), which represented the relationships between the social classes based on an analysis of the origin and appropriation of net product (distribution decision).

Economics, which can only be developed as a field of study based on the systematization introduced by accounting, is the mother of finance. In the daughter we can find the thoughts of Adam Smith, David Ricardo, and John Maynard Keynes. Adam Smith (1723-1790), a Scottish economist and philosopher, is considered the father of modern economics and the most important theorist of economic liberalism of the $18^{\text {th }}$ century. His main work, The wealth of nations, written in 1776, was of fundamental importance to the development of capitalism, by advocating for non-intervention of the state in the economy, limiting its role to guarding public safety, maintaining order, and guaranteeing private property. Adam Smith defended contractual freedom, via which employers and employees would be free to negotiate labor contracts. David Ricardo (17721823), in turn, was the son of a Dutch Jew who made his fortune on the stock exchange. Influenced by his father, he entered into the stock market at 14 and soon ensured his financial security, going on to focus on literature and science, especially mathematics, physics, and geology. In 1799, having read the work of Adam Smith, he became interested in economics. In 1817, we wrote Principles of political economy and taxation, which analyzes the laws that determine the distribution of all that can be produced by the three classes of the community: the landowners, the workers, and the owners of capital. The most well-known theory postulated by Ricardo is that of comparative advantages, which forms the conceptual basis for international trade by arguing that two nations can mutually benefit from free trade, even if one is less efficient in producing all types of goods than its trading partner. Closing the cycle of great economists who influenced finance is John Maynard Keynes (18831946), a British economist who, in The general theory of employment, interest and money (1936) and in How to pay for the war (1940), established, respectively, the theoretical foundations of modern macroeconomics and of national accounts, highlighting the importance of financing decisions.

Keynesian thinking defended the economic policy of an interventionist state, through which governments would use fiscal and monetary measures to mitigate the adverse effects of economic cycles (recessions, depressions, and booms). With the outbreak of the Second World War (1939-1945) and the heavy recession that followed, Keynes' interventionist thinking was adopted by the main economic powers of the West, only losing strength in the 1970s, due the economic problems that occurred in the United States of America and in England (the break from the gold standard and devaluation of the U.S. dollar, the oil crisis, trade deficits, inflation and economic stagnation, unemployment, social struggles, and xenophobic movements) and the criticisms of liberal economists, such as Milton Friedman, who were skeptical in relation to the state's ability to regulate economic cycles with fiscal policies. The successive economic crises that occurred at the end of the 1990s, however, led to the resurgence of Keynesian thinking, which was present on the government agenda of the U.S. president Barack Obama (2009-2017), the British prime minister Gordon Brown (2007-2010), and other world leaders concerned about avoiding a new wave of 1929-like recessions in the wake of the subprime mortgage crisis, which began in 2007. Today, in 2020, when the world is suffering from the COVID-19 pandemic, Keynesian thinking appears to be stronger than ever in the form of quantitative easing policies adopted by all governments around the world. This crisis has affected the development of accounting, by demanding new sets of information that can provide support to the governance and management of countries and businesses, feeding back into the innovation cycle between the three areas of finance, economics, and accounting. 


\section{THE DAUGHTER'S AUTONOMY}

Based on the counting and systematization methods developed in accounting and the relationships between the various agents studied by economics, the focal point of the financial theories has evolved considerably in the last 70 years, focusing on the analysis of the behavior of economic agents in the allocation of their scarce resources in time and space. Time and uncertainty are the elements that influence current financial behavior (Weston, 1966).

In the 1920s, the development of the post-First World War market provided large profit margins, and managers worried about controlling stocks and what would happen if the sharp fall in prices that occurred in 1920/1921 were to be repeated. To answer these questions, financial theory focused on studying the financial structure of companies and their liquidity. Studies on planning and control were also needed. In the 1930s, under the influence of the 1929 stock market crash, the concern moved to company reorganizations, bankruptcies, and mechanisms that guaranteed the financial recovery of firms, their solvency, and liquidity. In the 1940s, marked by the Second World War, all production went toward the war effort. The concern of companies and, therefore, the direction of financial theory, involved the obtainment of funding to increase production and meet the demand for consumer goods in the post-war period. In the 1950s, the expected economic expansion occurred, leading companies and finance scholars to fear the risk of a possible recession (like the one that occurred at the end of the First World War). Therefore, the studies focused on cash flow budgets and internal controls. This demand affected accounting in the sense that it adapted, segmenting information and adjusting the application of principles. The muchfeared recession did not occur and, in the 1960s, there was an excess of businesses competing with each other. Profitability began to decline. To face the competition, there were heavy investments in research and development and the creation of companies in alternative segments. Scarce capital and excess business opportunities led to greater concern about the cost of capital and the valuation of projects. Businesses also focused on increasing profits, independently of increasing sales. There was a movement toward the internationalization of companies located in mature markets in search of better opportunities.

Up until the 1960s, both the market theories and the corporate finance theories were ad hoc, and scholars focused their efforts on obtaining answers to the most urgent questions raised by the productive sector. The end of the 1950s, however, began to see a change in this paradigm. Analytical methods and economic theory began to be applied to financial problems, giving rise to positivist theories, at the expense of the normative questions presented up to then.

The years following the 1950s saw the emergence of the pillars of modern financial theory. Among these pillars are the efficient markets theory (which analyzes price change behavior over time in speculative markets), portfolio theory (which analyzes optimal asset selection procedures), corporate finance theories (the proposition of the irrelevance of financing decisions and earnings distribution in relation to company value), asset pricing theory (which analyzes the determinants of asset prices under uncertainty conditions), options pricing theory (which analyzes the determinants of the prices of contingent rights), and agency or representation theory (which analyzes the conflicts of interest that arise in contractual relationships, between agents and holders of capital or between representatives and those represented).

These theories have important implications in the field of corporate and market finance. Take the efficient markets theory, attributed to Fama (1965) and Samuelson (1965). Establishing that the capital market is efficient means accepting that a company's value is simply the present value of its future cash flows, discounting the cost of capital and the investments made. Thus, managers should always seek to maximize the company's current value, since this way they will also be seeking to maximize future cash flows, net of the cost of capital and incremental investments. In an efficient market, therefore, the prices of a company's shares are good estimators of the effect of the various policies adopted by the managers, duly recorded in the financial statements.

In the financial market, portfolio theory, initially developed by Arrow (1951) and Markowitz (1952), represents a milestone. Until the pioneering work of Markowitz (1952), little or no attention was paid to choosing assets under uncertainty conditions, which fulfilled the criterion of undervaluation, with portfolios formed based on stocks that were considered undervalued according to the traditional criteria, generally accounting multiples. Markowitz (1952) showed that this criterion is ineffective, as it overlooks the benefits of diversification over the risk of each asset. His mean-variance model provides a formal definition of the relevant risk, obtained through diversification, which is defined as the covariance between the stocks. Extrapolating the concept to the area of corporate finance, perhaps the greatest contribution 
of this theory is to show that companies should value projects in the same way that investors value stocks, that is, considering the effects of the decision to accept or reject new projects over already-existing projects and seeking to diversify their area of activity.

Tobin (1958) took Markowitz's (1952) approach a step further, recommending an efficient portfolio to be held by the investor. This portfolio serves as a benchmark for comparing the risk-return relationship of any project under risk. The optimal portfolio, however, does not depend on the investor's risk preferences - a proposition known as the separation theorem.

It was left to Treynor (1961), Sharpe (1964), and Lintner (1965) to transform Markowitz's (1952) and Tobin's (1958) analysis into a theory for determining asset prices given the relevant risk. Given the demand of investors for assets and assuming a fixed supply of those assets, these authors sought equilibrium prices in a single period, without transaction costs. This study gave rise to the capital asset pricing model (CAPM), which defined the fair return, given the relevant risk of any risk asset. This fair return is a fundamental input for companies' capital budget decisions, as the partners' cost of capital (own capital) for risky projects, with and without the presence of leverage, should be estimated in light of the separation theorem (benchmark) and the CAPM. Thus, asset pricing theory, associated with the market efficiency hypothesis, is also designed to determine prices (project values) equivalent to the company's future cash flows discounted at the cost of capital. Recording the information needed for this estimation, as well as the effects derived from the acceptance of new projects, is, as always, left to accounting.

Another important milestone of modern financial theory also emerged in this period: the propositions of Modigliani and Miller (M\&M) (1958), who established a theory of irrelevance for both financing decisions and for the distribution of earnings in relation to company value. These authors demonstrated that, considering that information about a company's prospective earnings and its investment policy are freely accessible, in the absence of taxes and transaction costs, the company's financing decision does not alter its present value, as the use of cheaper capital (debt) is exactly offset by the increase in the risk and return required by the own capital. Relaxing the initial conditions, M\&M accepted that it is only plausible for the financing structure to alter the company's present value under the following conditions: i. the presence of fiscal benefits derived from using debt;

ii. bankruptcy costs;

iii. agency costs: as the creditors delegate decision-making power to the managers, it is common for them to demand higher returns on their investments instead of ploughing profits back into new, less profitable investments as they have no grasp of the policies to be adopted by the company. Creditor demands may lead to the underinvestment problem, while the asymmetry caused by the use of debt may encourage overinvestment. Both effects are agency costs;

iv. signaling effects: considering that the individuals linked to the company (insiders) have more information about it than the investors, the choice of one or another form of financing may signal insider information to the market regarding the company's future. For example, the sale of large blocks of shares by insiders (and their substitution for debt) is generally accompanied by a fall in stock value.

In all these determinants, we observe the presence of accounting information with high informational content, capable of affecting project prices and viability.

Subsequently, M\&M extended capital structure analysis to the analysis of earnings distribution policy. Following the same logic, they argued that it is indifferent for the company whether it pays dividends or not, as these are financed by the sale of new shares or the issuing of debt, which do not alter the company's value (Miller \& Modigliani, 1961).

Since 1964, the propositions of M\&M, combined with the recently elaborated risk asset pricing model (CAPM), have served as the basis for defining the cost of own capital and the weighted average cost of capital to be used when valuing investment projects.

In the following decade, the advances in the financial theories were more surprising. The 1970s were primarily marked by the weakening of the U.S. dollar, a direct consequence of the American balance of payments deficit and rise in inflation. This devaluation led the U.S. government to abolish the gold standard defined at Bretton Woods, as the dollar-to-gold parity had given rise to overvaluation of the dollar compared to European currencies. Because of the enormous losses verified in the investments made in that period, investors paid attention to portfolio and risk analysis. The works of Markowitz (1952), Tobin (1958), and Sharpe (1964) were highly valued. 
In the 1980s, the banking crisis caused by the moratorium on emerging markets, a direct consequence of the disorderly entry of resources into the economy and the partition of these to emerging countries at low interest rates, resulted in the process of financial disintermediation and deregulation. At the same time, the junk bonds market emerged in the United States, which besides enabling the financing of small businesses, led to a wave of leveraged acquisitions and all manner of corporate restructurings. This period was especially beneficial for the application of the financial theories developed up to then. The study of risk became the center of attention, and futures and options markets, which could control the risk derived from fluctuations in spot prices, gained prominence.
Here, it is worth noting the importance of the work of Black and Scholes (1973).

Together with the greater sophistication of the market instruments, the investment valuation models also became more robust, considering intertemporal aspects and new sources of uncertainty. Markowitz's (1952) and Sharpe's (1964) static portfolio theory gave way to dynamic portfolio theory, with intertemporal models linked to consumption [intertemporal capital asset pricing model (ICAPM), consumption-based capital asset pricing model (CCAPM)]. Factor models also expanded the old singlerisk measure (beta) to multi-dimensional risk measures, illustrated in Ross' (1976) arbitrage pricing theory (APT) and in Fama and French's (1992) factors model.

\section{ACCOUNTING AND FINANCE: A VIRTUOUS RELATIONSHIP}

With the refinement of the market, the theory of agency (or of representation), which sought to analyze the problems associated with the structure of the agent's (or representative's) compensation, gained strength. This structure should align the incentives given to agents/ managers with the interests of principals/shareholders (or those represented). The development of the optimal contractual structure under agency theory is based on the works of Coase (1937), for whom agency problems are the main elements of the so-called "contractual vision of the business," and of Berle and Means (1932), which discussed the foundations of U.S. corporate law, exploring the evolution of large corporations and arguing that the separation between the legal control and managerial control of companies can generate problems that can be overcome by an effective remuneration system to align interests or rules and corporate governance mechanisms.

In the 1990s, the process of globalization of the economy began and there was an increase in off-balance sheet risks. Again, the inter-relationship between finance and accounting drove the studies developed. There was a movement on the part of companies to evaluate business opportunities around the world and a focus on the creation of shareholder value. Leveraged acquisitions decreased in relation to the previous decade, but the concern about controlling risks remained and other derivatives were created in order to minimize the risk of financing operations. Financial engineering was established definitively. Finance created what accounting was responsible for recording in the most evident way for the various users. The financial innovations that occurred in this period were not, however, motivated by the same factors verified in the 1970s and 1980s: high market volatility and the accelerated rise in interest rates gave way to a market with credit constraints and quite high spreads, despite the consistency of the rates. In order to obtain sources of funding at a desirable cost, riskier businesses had to resort to financial instruments. In this decade, one of the strongest criticisms not only of the CAPM but, especially, of the efficient markets theory, was formulated by Haugen (1995). This author defended the idea that the capital market is highly inefficient and subject to the overreaction effect, where the highest (lowest) risk assets are those that generate the lowest (highest) returns. Haugen's (1995) criticism goes so against the theories presented up to then that the author suggested that the previous ideas be placed under the label of "modern finance," while his theories would form "new finance."

\section{CRITICISMS AND CONTROVERSIES DRIVE STUDIES IN FINANCE}

Haugen's (1995) core proposal is that investors are so irrational that, based on the company's past performance, they price growth stocks (stocks in companies with a low book value/market value ratio, for which above-average growth is expected) at such a high level that any negative surprise causes a sharp fall in the price (overreaction effect). In contrast, value stocks (stocks in companies with a high book value/market value ratio, for which lower growth rates are expected) are priced at such a low level that any positive surprise raises their price level and, 
therefore, their returns. Behind this proposition is the rejection of the market efficiency hypothesis: investors receive information, but, not knowing how to evaluate it completely, form prices that are inconsistent with the company's "real" future.

Haugen's (1995) criticism also goes against the riskreturn relationship. The author affirms that value stocks, which are potential generators of higher returns, are also the lowest-risk stocks, a hypothesis that completely invalidates the CAPM. His proposition is based on the fact that investors expect so much from growth stocks that any surprise makes their returns fluctuate excessively, increasing their risk. Value stocks, in turn, are so neglected that their returns tend to be more stable.

In light of the irrationalities indicated by Haugen (1995), new theories emerged with the aim of making the premise of unlimited decision-maker rationality more flexible. The field of behavioral finance, which began based on the research of Tversky and Kaheman back in 1973, under the judgement of uncertainty, currently occupies a relevant space in the new research. Unlike what the normative approach may suggest, people often make non-optimal decisions from a rational model viewpoint and, in this case, it is more important to understand the reasons for which this occurs. The pioneering works in this line were developed at the end of the 1950s by Simon (March \& Simon, 1958; Simon, 1957), who proposed that although individuals sought rational solutions their capacity for judgement was limited by their own rationality (bounded rationality).

As well as these constraints on processing information, decision makers usually lack important information due to limited time and cost, which, in turn, limits the quantity and quality of the information. Therefore, not only does the decision maker's own mental capacity restrict the volume of data, criteria, scenarios, and alternatives that can be properly taken into account when calculating the optimal decision, but this information is also restricted, with it being left to accounting to refine its records in order to alleviate this constraint.

\section{AND SO PROGRESSES THE THEORETICAL-EMPIRICAL RESEARCH}

Besides the whole theoretical evolution that has occurred in the field of finance, another revolution focusing on the experiments needed to test these theories has also occurred. The works with mere descriptive statistics (mean, variance, asymmetry, coefficient of variation) have given way to others with a more sophisticated design, involving univariate, multivariate, time series, and, more recently, panel data regressions (where time and observational units are considered together). Currently, there is a considerable demand related to controlling the endogeneity of the regressors, one of the biggest problems encountered by the empirical works in finance. For that reason, control mechanisms for more sophisticated treatments, estimating counterfactuals and calculating differences in differences, as well as the use of multi-level and discontinuous regressions and non-linear search algorithms, have often emerged.

This journey since the $15^{\text {th }}$ century through the field of finance and its twin areas, accounting and economics, serves to highlight the evolution of the area and the comprehensive nature of the Accounting \& Finance Review
(RC\&F) in receiving and publishing papers on all the topics that interest its researchers. In this edition, for example, there are papers on so-called efficient market anomalies (the January effect); the choice of capital structure, considering the influence of the macroeconomic context and the innovative profile of the borrowing firms; other forms of financing through own capital (crowdfunding); factors that are able to affect the correct asset pricing (such as the presence of outliers); the choice of assets for investment (pension funds); the influence of foreign capital flow on market liquidity; a discussion regarding earnings dividend policy and dividends growth; and determinants of bankruptcy using causal forest algorithms. As can be seen, a single edition of RC\&F provides elements for discussing centuries of theories. It is for no other reason that the review is considered a compulsory source of information by researchers who wish to understand the latest developments in this highly complex and fascinating area of corporate and market finance. I wish you a rewarding journey through the knowledge and an enjoyable read! 


\section{REFERENCES}

Arrow, K. J. (1951). Alternative approaches to the theory of choice in risk-taking situations. Econometrica, 19(4), 404-437.

Berle, A., Means, G. (1932). The modern corporation and private property. Macmillan.

Black, F., Scholes, M. (1973). The pricing of options and corporate liabilities. Journal of Political Economy, 81(3), 637-659.

Coase, R. (1937). The nature of firm. Economica, 4(16), 386-405.

Fama, E. (1965). The behavior of stock prices. Journal of Business, 38(1), 34-105.

Fama, E., French, K. (1992). The cross-section of expected stock returns. Journal of Finance, 47(2), 427-465.

Hallak J., Neto. (2014). O sistema de contas nacionais: Evolução, principais conceitos e sua implantação no Brasil. Instituto Brasileiro de Geografia e Estatística.

Haugen, R. (1995). The new finance: The case against efficient markets. Contemporary.

Iudícibus, S. de. (1997). Teoria da contabilidade (5 $5^{\text {th }}$ ed.). Atlas.

Law n. 6,404, of December $15^{\text {th }}$ of 1976 (December $15^{\text {th }}, 1976$ ). Discusses Joint-Stock Companies. http://www.planalto.gov.br/ ccivil_03/leis/L6404consol.htm

Lintner, J. (1965). The valuation of risk assets and the selection of risky investments in stock portfolios and capital budgets. Review of Economics and Statistics, 47(1), 13-37.

March, J., Simon, H. (1958). Organizations. Wiley.
Markowitz, H. (1952). Portfolio selection. The Journal of Finance, 7(1), 77-91.

Miller, M., Modigliani, F. (1961). Dividend policy, growth, and the valuation of shares. Journal of Business, 34(4), 411-433.

Modigliani, F., Miller, M. (1958). The cost of capital, corporation finance and the theory of investment. American Economic Review, 48(3), 261-297.

Ross, S. A. (1976). Arbitrage theory of capital asset pricing. Journal of Economic Theory, 13(3), 341-360.

Samuelson, P. A. (1965). Proof that properly anticipated prices fluctuate randomly. Industrial Management Review, 6(1), 41-49.

Sharpe, W. F. (1964). Capital assets prices: A theory of market equilibrium under conditions of risk. Journal of Finance, 19(3), 425-442.

Simon, H. (1957). Models of man. John Wiley and Sons.

Tobin, J. (1958). Liquidity preference as a behavior toward risk. Review of Economic Studies, 25(1), 65-86.

Treynor, J. L. (1961). Toward a theory of market value of risky assets [Mimeo], subsequently published in Korajczyk, R. A. (1999). Asset pricing and portfolios performance: Models, strategy and performance metrics. Risk Books.

Tversky, A., Kahneman, D. (1973). Judgment under uncertainty: Heuristics and biases. Science, 185(4157), 1124-1131.

Weston, J. F. (1966). The scope and methodology of finance ( $\left.1^{\text {st }} \mathrm{ed}.\right)$. Prentice Hall. 


\section{Erratum}

In the editorial “Accounting \& Finance, a close relationship", with DOI number: 10.1590/1808-057x202090340, published in the journal Revista Contabilidade \& Finanças, 31(84): 385-391, on page 385:

\section{Where it reads:}

${ }^{1}$ Universidade Federal de Juiz de Fora, Faculdade de Economia, Programa de Pós-Graduação em Economia, Juiz de Fora, RJ, Brazil

Correspondence address:

Fernanda Finotti Cordeiro

Universidade Federal de Juiz de Fora, Faculdade de Economia, Programa de Pós-Graduação em Economia

Campus Universitário - CEP 36036-330

Martelos - Juiz de Fora - RJ - Brasil

\section{It shall be read:}

${ }^{1}$ Universidade Federal de Juiz de Fora, Faculdade de Economia, Programa de Pós-Graduação em Economia, Juiz de Fora, MG, Brazil

Correspondence address:

Fernanda Finotti Cordeiro

Universidade Federal de Juiz de Fora, Faculdade de Economia, Programa de Pós-Graduação em Economia

Campus Universitário - CEP 36036-330

Martelos - Juiz de Fora - MG - Brasil 
ERRATUM

\section{Erratum}

In the editorial "Accounting \& Finance, a close relationship", published in the journal Revista Contabilidade \& Finanças, 31(84): 385-391, on page 385:

Where it reads:

DOI: $10.1590 / 1808-057 x 202090340$

It shall be read:

DOI: $10.1590 / 1808-057 \times 202090350$ 